DOI: 10.19195/0137-1134.116.1

\author{
ALEKSANDRA BUDNIAK-ROGALA \\ ORCID: 0000-0003-1391-3506 \\ Uniwersytet Wrocławski \\ Okręgowa Rada Adwokacka we Wrocławiu
}

\title{
WYŁĄCZENIE BIEGŁEGO W POSTĘPOWANIU ARBITRAŻOWYM
}

\begin{abstract}
Abstrakt: Ustawodawca nie wprowadził do kodeksu postępowania cywilnego wyraźnej regulacji statuującej podstawę prawną wyłączenia biegłego w postępowaniu arbitrażowym. Problematyczne pozostaje zatem, czy i na jakich zasadach miałoby to ewentualnie nastąpić.

Postępowanie przed sądem polubownym wykazuje zupełnie odrębną specyfikę w porównaniu do postępowania sądowego. W konsekwencji rzutuje to na odmienność reguł odnoszących się do postępowania dowodowego, szczególnie w zakresie zasad przeprowadzania dowodu z opinii biegłego. W postępowaniu arbitrażowym - inaczej niż w postępowaniu sądowym — stosowane są dwa modele w odniesieniu do omawianego środka dowodowego. Standardowo możliwe jest wyznaczenie biegłego przez sąd polubowny. Przeważa jednak praktyka, zgodnie z którą biegły arbitrażowy wyznaczany jest przez strony. Uzasadnia to odmienne potraktowanie kwestii wyłączenia biegłego, w zależności od źródła jego powołania.

Odnosząc się do przypadku biegłego powołanego przez sąd arbitrażowy, warto odnotować, że zgodnie z treścią przepisu art. $1184 \S 2$ zd. 2 k.p.c. sąd polubowny nie jest związany przepisami o postępowaniu przed sądem. W związku z tym w postępowaniu arbitrażowym nie ma podstawy do zastosowania na mocy reguły z art. $13 \S 2$ k.p.c. przepisu art. 281 k.p.c dotyczącego wyłączenia biegłego sądowego. Wydaje się jednak, że w analizowanym zakresie można posiłkować się wytycznymi IBA dotyczącymi konfliktu interesów w międzynarodowym arbitrażu handlowym. Biegłemu powołanemu przez stronę wypada natomiast przypisać status świadka mającego wiedzę specjalistyczną (expert witness). W takim ujęciu nie ma potrzeby posiłkowania się w analizowanym zakresie konstrukcją wyłączenia biegłego, omawiany środek dowodowy podlega bowiem ocenie na zasadach odnoszących się do dowodu z zeznań świadka.
\end{abstract}

Słowa kluczowe: dowód z opinii biegłego, postępowanie arbitrażowe, biegły w postępowaniu arbitrażowym, wyłączenie biegłego, wyłączenie biegłego w postępowaniu arbitrażowym

\section{UWAGI WSTĘPNE}

Kwestia wyłączenia biegłego w arbitrażu nie została expressis verbis uregulowana w treści przepisów kodeksu postępowania cywilnego. W konsekwencji problematyczny pozostaje sposób i skutki weryfikacji przedmiotowego dowodu $\mathrm{w}$ ramach postępowania przed sądem polubownym. 


\section{ODMIENNOŚĆ POSTĘPOWANIA ARBITRAŻOWEGO I POSTĘPOWANIA SĄDOWEGO - ZE SZCZEGÓLNYM UWZGLĘDNIENIEM ZASAD DOTYCZĄCYCH PRZEPROWADZANIA DOWODÓW}

Odnosząc się do analizowanej kwestii, warto na wstępie zwrócić uwagę przede wszystkim na odrębność postępowania arbitrażowego i postępowania sądowego. Sąd arbitrażowy — odmiennie niż sąd powszechny — nie sprawuje bowiem wymiaru sprawiedliwości ${ }^{1}$. Z kolei sąd państwowy pełni w ramach postępowania przed sądem polubownym funkcję jedynie pomocniczą — zakres czynności sądu powszechnego w postępowaniu arbitrażowym pozostaje bowiem ograniczony jedynie do kompetencji wyraźnie wskazanych w przepisach ustawy (vide przykładowo art. 1159 § 1 k.p.c., a w odniesieniu do postępowania dowodowego też art. 1192 k.p.c.) $)^{2}$.

Oba wymienione postępowania rządzą się również zupełnie odmiennymi zasadami. Wprawdzie zarówno w arbitrażu, jak i postępowaniu sądowym rozpoznawane są sprawy cywilne w rozumieniu art. 1 k.p.c. ${ }^{3}$ Warto jednak podkreślić, że dominującą rolę $\mathrm{w}$ ramach sądownictwa polubownego odgrywa arbitraż międzynarodowy (w tym szczególnie międzynarodowy arbitraż handlowy). Wykazuje on w konsekwencji priorytetowe znaczenie w zakresie tworzenia praktyki arbitrażowej, także w odniesieniu do kształtowania (zasad) postępowania dowodowego ${ }^{4}$. Nie sposób natomiast równocześnie pominąć faktu, że sądownictwo polubowne stanowi specyficzną dziedzinę prawa, w której obrębie stykają się różne (i przeciwstawne) zasady kultury prawnej — common law i civil law. To właśnie na gruncie postępowania przed sądem arbitrażowym przenikanie wspomnianych zasad wydaje się najbardziej widoczne - w efekcie powstaje taki model postę-

${ }^{1}$ Szerzej w tym kontekście zob. A. Budniak-Rogala, Charakter prawny zapisu na sąd polubowny w postepowaniu cywilnym, Wrocław 2015, s. 37 n. oraz cyt. tam literatura.

2 Zob. T. Ereciński, K. Weitz, Sąd arbitrażowy, Warszawa 2008, s. 58-60. W tym zakresie por. też M. Łaszczuk, J. Szpara, Uwagi o zakresie pomocy udzielanej sądowi polubownemu przez sąd państwowy na podstawie art. 1192 k.p.c., „Palestra” 2008, z. 9-10, s. 27 n.; K. Weitz, Przesłanki i zakres pomocy sadu państwowego dla sądu polubownego w postępowaniu dowodowym (art. 1192 k.p.c.), ADR 2009, nr 2, s. 107 n. Zob. także A. Budniak-Rogala, Czy wszczęcie postępowania pojednawczego w sprawie objętej zapisem na sad polubowny stanowi nadużycie prawa procesowego?, [w:] Ius est ars boni et aequi. Księga pamiątkowa dedykowana Profesorowi Józefowi Frackowiakowi, red. A. Dańko-Roesler et al., Wrocław 2018, s. 125-141 oraz cyt. tam literatura.

3 Por. przykładowo S. Cieślak, Stosunek postępowania arbitrażowego do innych rodzajów postępowania cywilnego, ADR 2011, nr 4, s. 17 oraz cyt. tam literatura.

${ }^{4}$ W tym kontekście por. też T. Ereciński, Zagadnienia prawa właściwego i postępowania dowodowego w międzynarodowym arbitrażu handlowym, PiP 1987, z. 9, s. 49 n. Odnośnie do pojęcia arbitrażu handlowego (w tym również międzynarodowego arbitrażu handlowego) zob. przede wszystkim A. Szumański, Pojęcie, rodzaje i charakter prawny arbitrażu handlowego, [w:] System Prawa Handlowego, red. S. Włodyka, A. Szumański, „Arbitraż Handlowy” 8, red. A. Szumański, Warszawa 2015, nb 1 n., s. 8 n. 
powania, który nie daje się jednoznacznie zakwalifikować ani do jednej, ani do drugiej z wymienionych kultur ${ }^{5}$. W związku z tym w doktrynie podkreśla się z jednej strony, że ,instrumenty arbitrażowe cechuje eklektyczność, która umoż-

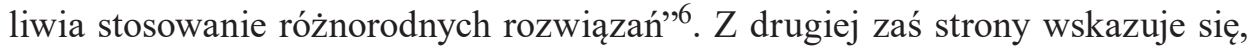
że ,uczestnictwo w arbitrażu wymaga pewnej krytycznej refleksji i odrzucenia instynktownie przyjmowanych reguł"'?

Równocześnie zasadniczo nie ulega wątpliwości, że sąd powszechny pozostaje związany przepisami o postępowaniu sądowym, w tym szczególnie regulacjami kodeksu postępowania cywilnego. Zgodnie natomiast z treścią art. $1184 \S 2 \mathrm{zd}$. 2 k.p.c. sąd polubowny nie jest związany przepisami o postępowaniu przed sądem ${ }^{8}$. Odmienna specyfika postępowania sądowego i arbitrażowego w konsekwencji niewątpliwie rzutuje na odrębność reguł odnoszących się do postępowania dowodowego ${ }^{9}$. Zasady związane z przeprowadzaniem dowodów przez sąd państwowy zostały szczegółowo określone w treści regulacji z art. 227-315 k.p.c. Postępowanie dowodowe w arbitrażu jest z kolei uregulowane jedynie fragmentarycznie zaledwie na podstawie przepisów art. 1191 i 1192 k.p.c. Przedmiotowe rozwiązanie znajduje zapewne uzasadnienie w treści art. $1184 \S 1$ k.p.c., który ustanawia priorytet decyzji stron odnośnie do ustalenia zasad i sposobu postępowania przed sądem polubownym, o ile przepis ustawy nie stanowi inaczej. Natomiast w myśl art. $1184 \S 2$ zd. 1 k.p.c. w braku odmiennego uzgodnienia stron sąd polubowny może, z zastrzeżeniem przepisów ustawy, prowadzić postępowanie w taki sposób, jaki uzna za właściwy ${ }^{10}$.

5 Tak K. Weitz, Wykład inauguracyjny na Konferencji pt. „Dowód z opinii biegłego w sqdowym postępowaniu cywilnym $i$ w arbitrażu”, Warszawa 23.05.2017. W tym kontekście por. też T. Ereciński, Zagadnienia prawa właściwego..., s. 49 n.

${ }^{6} \mathrm{~K}$. Czech, Dowody i postępowanie dowodowe w międzynarodowym arbitrażu handlowym oraz inwestycyjnym, Warszawa 2017, s. 281.

7 Tak M. Jamka, Dowód z zeznań świadka w krajowej i międzynarodowej praktyce arbitrażowej, [w:] Księga pamiątkowa 60-lecia Sadu Arbitrażowego przy Krajowej Izbie Gospodarczej w Warszawie, red. J. Okolski et al., Warszawa 2010, s. 179.

8 Ibidem.

9 W tym kontekście por. też (ale przede wszystkim w odniesieniu do dowodów z dokumentów lub z zeznań świadków): Ł. Błaszczak, M. Ludwik, Sądownictwo polubowne (arbitraż), Warszawa 2007, s. 169; A. Jakubecki, [w:] Kodeks postępowania cywilnego. Komentarz, t. 5. Art. 1096-1217, red. H. Dolecki, T. Wiśniewski, Warszawa 2013, s. 506-507; T. Ereciński, [w:] Kodeks postępowania cywilnego. Komentarz, t. 6. Międzynarodowe postępowanie cywilne. Sąd polubowny (arbitrażowy), red. T. Ereciński, Warszawa 2017, s. 955; R. Morek, A. Budniak-Rogala, [w:] Kodeks postępowania cywilnego. Komentarz, red. E. Marszałkowska-Krześ, Legalis 2019, komentarz do art. 1191 k.p.c., nb 5.

10 Szerzej zob. przykładowo R. Kulski, Postepowanie dowodowe przed sądami polubownymi w ujęciu prawa polskiego i prawa amerykańskiego, [w:] Mediacja i arbitraż jako instrumenty wspierania przedsiębiorczości, red. J. Olszewski, B. Sagan, R. Uliasz, Rzeszów 2006, s. 115-117; B. Gessel-Kalinowska vel Kalisz, Przyczynek do rozważań na temat odrębności postępowania dowodowego w sprawach rozstrzyganych przez sądy polubowne, ADR 2009, nr 1, s. $89 \mathrm{n}$. W tym zakresie por. też T. Ereciński, Zagadnienia prawa właściwego..., s. 49 n. 


\section{SPECYFIKA DOWODU Z OPINII BIEGŁEGO W POSTĘPOWANIU ARBITRAŻOWYM}

Przyjęta konstrukcja niewątpliwie wpływa na specyfikę dowodu z opinii biegłego w postępowaniu przed sądem polubownym. Podobnie jak całe postępowanie dowodowe w arbitrażu omawiany środek dowodowy również został uregulowany bardzo wąsko - do dowodu z opinii biegłego ustawodawca odnosi się bowiem in concreto jedynie w treści przepisów art. 1191 § 2 i 3 k.p.c. Wspomniana regulacja statuuje $\mathrm{z}$ kolei priorytet decyzji stron $\mathrm{w}$ zakresie określenia zasad i sposobu przeprowadzenia dowodu z opinii biegłego w arbitrażu. Przepisy art. 1191 § 2 i 3 k.p.c. stanowią bowiem expressis verbis, że ustalone na ich mocy reguły mają zastosowanie „w braku odmiennego uzgodnienia stron”"l1.

W zakresie dotyczącym arbitrażu międzynarodowego podstawowe zasady traktowane jako pewien wzorzec zadań i statusu biegłych w postępowaniu arbitrażowym wynikają przede wszystkim z kilku dokumentów wydanych przez międzynarodowe instytucje i trybunały arbitrażowe. Należy do nich zaliczyć przede wszystkim Regulamin Dowodowy IBA ${ }^{12}$, Regulamin UNCITRAL ${ }^{13}$ oraz Regulamin ICC ${ }^{14}$, a także Protokół CIArb ${ }^{15}$ i Wytyczne CIArb ${ }^{16}$. Wszystkie te dokumenty stanowią ważne wytyczne dotyczące wykorzystania biegłych oraz ich działalności w ramach międzynarodowego postępowania arbitrażowego i zawierają regulacje dotyczące przedmiotowej problematyki w zakresie bardziej szczegółowym niż większość przepisów pochodzenia krajowego dotyczących postępowa-

11 Por. też T. Ereciński, K. Weitz, op. cit., s. 318; B. Krużewski, R. Kos, M. Modzelewska de Raad, Wyznaczenie biegłego, [w:] Dowód z opinii biegłego w postępowaniu arbitrażowym. Raport Komisji ds. Arbitrażu Naczelnej Rady Adwokackiej, red. M. Łaszczuk, R. Morek, Warszawa 2016, s. 12-13.

12 Regulamin Dowodowy IBA (IBA Rules on the Taking of Evidence in International Arbitration) wydany przez Międzynarodowe Stowarzyszenie Adwokatów (IBA International Bar Association) - Regulamin IBA przeprowadzania dowodów w arbitrażu międzynarodowym, zatwierdzony 29 maja 2010 roku przez Radę Międzynarodowego Stowarzyszenia Prawników.

13 Regulamin UNCITRAL (Regulamin Arbitrażowy UNCITRAL, UNCITRAL Arbitration Rules/Arbitration Rules of the United Commission on International Trade Law) - Regulamin Komisji Narodów Zjednoczonych ds. Międzynarodowego Prawa Handlowego (UNCITRAL/United Nations Commission on International Trade Law).

14 Regulamin ICC (ICC Rules of Arbitration/International Chamber of Commerce Rules of Arbitration) — Regulamin (Postępowania Arbitrażowego) Międzynarodowego Trybunału Arbitrażowego przy Międzynarodowej Izbie Handlowej (ICC — International Chamber of Commerce).

15 Protokół CIArb (CIArb Protocol of Use of Party-Appointed Expert Witnesses in International Arbitration) - opracowany przez CIArb (Chartered Institute of Arbitrators) protokół dotyczący wykorzystania dowodu z opinii biegłych wyznaczonych przez strony w arbitrażu międzynarodowym.

16 Wytyczne CIArb (CIArb Guidelines on the use of Tribunal-Appointed Experts, Legal Advisers and Assesors) - opracowane przez CIArb (Chartered Institute of Arbitrators) wytyczne dotyczące wykorzystania dowodu z opinii biegłych wyznaczonych przez zespół orzekający oraz doradców prawnych i technicznych. 
nia arbitrażowego ${ }^{17}$. Jednocześnie nie ulega kwestii, że ustalenia w omawianym zakresie mogą zawierać również regulaminy stałych sądów arbitrażowych (przykładowo Regulamin Sądu Arbitrażowego przy KiG ${ }^{18}$, Regulamin Sądu Arbitrażowego przy Konfederacji Lewiatan ${ }^{19}$ czy Regulamin Sądu Arbitrażowego przy DIG we Wrocławiu ${ }^{20}$ ). Jednak niezależnie od tego wiele postępowań tego rodzaju toczy się na zasadach określonych autonomicznie przez same strony lub przez trybunał arbitrażowy ${ }^{21}$.

Ustalenie przez strony zasad pracy biegłego arbitrażowego, obowiązujących w danym postępowaniu może nastąpić już w samym zapisie na sąd polubowny. W praktyce przyjmuje ono bardzo często postać odwołania do regulaminu stałej instytucji arbitrażowej (przykładowo do Regulaminu Sądu Arbitrażowego przy KIG - $§ 33$ ust. 5, 11 i 12) lub stosowanych w praktyce dokumentów o charakterze soft law (takich jak Regulamin Dowodowy IBA — art. 5 i 6). Ustalenia w przedmiotowym zakresie mogą zostać podjęte przez strony również w ramach postępowania arbitrażowego ${ }^{22}$. W braku określenia przez strony zasad i sposobu przeprowadzenia dowodu z opinii biegłego decyzję w przedmiotowym zakresie podejmuje sąd arbitrażowy, po zapoznaniu się ze stanowiskiem stron ${ }^{23}$. W przypadku powołania biegłego przez strony zasady jego pracy powinny zostać sprecyzowane zasadniczo już w pierwszym postanowieniu organizacyjnym, określającym przebieg postępowania arbitrażowego. W sytuacji gdy biegłego powołuje zespół orzekający, reguły związane ze złożeniem przez niego opinii mogą zostać określone (po ewentualnej dodatkowej konsultacji z biegłym) w postanowieniu o dopuszczeniu takiego dowodu lub w dokumencie określającym zadania biegłego, nazywanym

17 A.J. Bělohlávek, R. Hótová, Biegli w środowisku międzynarodowym w postępowaniu: sądowym, cywilnym i karnym oraz arbitrażowym, a także w sporach inwestycyjnych, Warszawa 2011, s. 168.

18 Regulamin Sądu Arbitrażowego przy Krajowej Izbie Gospodarczej w Warszawie w brzmieniu obowiązującym od dnia 1 stycznia 2015 roku, https:/sakig.pl/wp-content/uploads/2018/12/regulamin-arbitrazowy-tekst-jednolity-2015.pdf (dostęp: 8.05.2019).

19 Regulamin Sądu Arbitrażowego przy Konfederacji Lewiatan w brzmieniu obowiązującym od dnia 1 marca 2012 roku ze zmianami obowiązującymi od dnia 23 marca 2015 roku oraz od dnia 8 maja 2017 roku, http://www.sadarbitrazowy.org.pl/repository/Regulaminy/regulamin2017-PL-99x210-nowy.pdf (dostęp: 8.05.2019).

20 Regulamin Sądu Arbitrażowego przy Dolnośląskiej Izbie Gospodarczej we Wrocławiu, http://www.sa.dig.wroc.pl/files/regulamin_pl.pdf (dostęp: 8.05.2019).

21 A.J. Bělohlávek, R. Hótová, op. cit., s. 168.

22 Tak J. Szpara, Podstawowe zasady dotyczace pracy biegłego, [w:] Dowód z opinii biegłego..., s. 31. Por. też M. Łaszczuk, R. Morek, [w:] Regulamin Arbitrażowy Sąu Arbitrażowego przy KIG. Komentarz, red. M. Łaszczuk, A. Szumański, Warszawa 2017, s. 348.

23 W tym zakresie por. też T. Ereciński, K. Weitz, op. cit., s. 319; A.J. Bělohlávek, R. Hótová, op. cit., s. 169, 172-173, 175, 196; M. Łaszczuk, R. Morek, Uwagi wprowadzajace, [w:] Dowód z opinii biegłego..., s. 11; M. Łaszczuk, R. Morek, [w:] Regulamin Arbitrażowy Sądu Arbitrażowego..., s. 373; B. Krużewski, R. Kos, M. Modzelewska de Raad, op. cit., s. 13; K. Czech, op. cit., s. 355-360. Zob. także art. 6 ust. 1 Regulaminu Dowodowego IBA i art. 29 ust. 1 Regulaminu UNCITRAL. 
aktem misji (terms of reference) ${ }^{24}$. Równocześnie warto podkreślić, że strony mają istotny wpływ na określenie treści postanowienia dowodowego wydawanego przez sąd arbitrażowy (co pozwala lepiej sprecyzować zakres okoliczności, które mają być przedmiotem opinii), a także na przeprowadzenie dowodu i jego ewentualne uzupełnienie (w formie zarówno pisemnej, jak i ustnej) ${ }^{25}$. Ostatecznie wypada mieć jednak na względzie, że zasady pracy biegłego (niezależnie od ich źródła) powinny każdorazowo uwzględniać specyfikę danego postępowania arbitrażowego; nie mogą równocześnie naruszać przepisów o charakterze iuris cogentis ${ }^{26}$.

W konsekwencji dowód z opinii biegłego w postępowaniu arbitrażowym wykazuje zupełnie odmienną specyfikę w porównaniu do postępowania sądowego ${ }^{27}$.

Po pierwsze, warto podkreślić, że na zasadzie art. $278 \S 1$ in principio k.p.c. biegły sądowy jest powoływany w sytuacji, gdy niezbędne są wiadomości specjalne. Natomiast przepis art. $1191 \S 2$ k.p.c. nie wprowadza takiego zastrzeżenia w odniesieniu do biegłego arbitrażowego - analizowany wymóg można jednak wywieść z istoty omawianego środka dowodowego. Niezależnie od tego dowód z opinii biegłego w postępowaniu sądowym wykazuje w stosunku do dowodu z opinii biegłego $\mathrm{w}$ postępowaniu przed sądem polubownym istotną różnicę - $\mathrm{i}$ to różnicę natury fundamentalnej. Nie ulega bowiem wątpliwości, że w postępowaniu sądowym przeprowadzenie dowodu z opinii biegłego ma charakter obligatoryjny w każdej sytuacji, w której dla rozstrzygnięcia sprawy niezbędna jest wiedza specjalistyczna, nawet jeśli sędzia dysponuje taką wiedzą z uwagi na swoje doświadczenie lub wykształcenie. Zupełnie odmiennie kształtuje się natomiast przedmiotowa kwestia w postępowaniu arbitrażowym. W postępowaniu przed sądem polubownym wybiera się często konkretnych arbitrów właśnie z uwagi na posiadanie swoistej specjalistycznej wiedzy lub znajomość konkretnego systemu prawnego. Zastosowanie przedmiotowej konstrukcji pozwala bowiem zapobiec konieczności powoływania biegłych ${ }^{28}$. Co więcej, z uwagi na fakt, że w arbitrażu obowiązuje priorytet woli stron w zakresie określenia zasad i sposobu przeprowadzenia dowodu z opinii biegłego, same strony decydują o tym, w jakim kształcie

24 Tak J. Szpara, op. cit., s. 31-32. Odnośnie do aktu misji (terms of reference) zob. B. Krużewski, R. Kos, M. Modzelewska de Raad, op. cit., s. 27-29; M. Łaszczuk, R. Morek, [w:] Regulamin Arbitrażowy Sądu Arbitrażowego..., s. 342-343. W tym zakresie por. także B. Krużewski, Biegły w postępowaniu arbitrażowym, [w:] Księga pamiatkowa 60-lecia Sądu Arbitrażowego..., s. 220.

25 M. Łaszczuk, R. Morek, Uwagi wprowadzajace, [w:] Dowód z opinii biegłego..., s. 9.

26 Podobnie J. Szpara, op. cit., s. 32.

27 Tak i więcej zob. K. Czech, op. cit., s. 287-288 wraz z powołaną tam doktryną oraz s. 290 i 362 .

28 Tak K. Weitz, Wykład inauguracyjny na Konferencji... W tym zakresie por. też B. Krużewski, op. cit., s. 217-218; A.J. Bělohlávek, R. Hótová, op. cit., s. 164-165 i 198-201; B. Gessel-Kalinowska vel Kalisz, M. Dudzińska, [w:] Postępowanie przed sądem polubownym. Komentarz do Regulaminu Sąu Arbitrażowego przy Konfederacji Lewiatan, red. B. Gessel-Kalinowska vel Kalisz, Warszawa 2016, s. 454. Po części odmiennie (jak się wydaje) T. Ereciński, K. Weitz, op. cit., s. 319. 
dowód ten ma być przeprowadzony. W konsekwencji strony mogą ograniczyć zakres czynności biegłego, mogą nawet wyłączyć przeprowadzenie dowodu z opinii biegłego w danym postępowaniu. Regulacje w przedmiotowym zakresie nie moga jednak naruszać przepisów o charakterze iuris cogentis, a także podstawowych zasad postępowania arbitrażowego ${ }^{29}$. Ostatecznie warto mieć na względzie, że również sam sąd arbitrażowy może nie wyrazić zgody na przeprowadzenie dowodu z opinii biegłego w sytuacji, gdy członkowie składu orzekającego posiadają wiadomości specjalne, konieczne dla rozstrzygnięcia sprawy; jeżeli jednak trybunał arbitrażowy nie dysponuje wiedzą specjalistyczną w niezbędnym zakresie, nie może wówczas nie uwzględnić wniosku strony w tym przedmiocie ${ }^{30}$.

Po drugie, nie sposób pominąć faktu, że w systemach opierających się na prawie zwyczajowym (common law) biegli są zazwyczaj powoływani przez strony, natomiast w krajach o tradycji prawa stanowionego (civil law) biegli są powoływani zasadniczo przez sąd (zespół orzekający) ${ }^{31}$. W konsekwencji te dwa odmienne warianty sposobu powoływania biegłych przejawiają się analogicznie również w międzynarodowym arbitrażu handlowym. W doktrynie wskazuje się w tym kontekście, że jak dotąd nie występują wprawdzie żadne oznaki konsensusu (pomiędzy wspomnianymi odmiennymi kulturami prawnymi) w omawianym zakre$\mathrm{sie}^{32}$. Jednak równocześnie podkreśla się przy tym, że postępowanie arbitrażowe znajduje się pod coraz mocniejszym wpływem tradycji common law. Dzieje się tak przede wszystkim z powodu internacjonalizacji tego typu postępowań oraz ze względu na hegemonię języka angielskiego, który zdecydowanie dominuje w trybunałach arbitrażowych. Tendencja ta pozostaje niezależna od miejsca prowadzenia arbitrażu (tak zwanej siedziby arbitrażu), które może znajdować się również w państwie kultury prawnej civil law ${ }^{33}$.

Zatem w postępowaniu arbitrażowym — odmiennie niż w postępowaniu sądowym — w odniesieniu do omawianego środka dowodowego stosowane są dwa

29 Tak K. Weitz, Wykład inauguracyjny na Konferencji... W analizowanym kontekście zob. także T. Ereciński, Zagadnienia prawa właściwego..., s. 49 n.; P. Nowaczyk, [w:] P. Nowaczyk, A. Szumański, M. Szymańska, Regulamin Arbitrażowy UNCITRAL. Komentarz, Warszawa 2011, s. 384-385; B. Gessel-Kalinowska vel Kalisz, M. Dudzińska, op. cit., s. 455. Zob. też T. Ereciński, [w:] Kodeks postępowania cywilnego..., s. 956; M. Łaszczuk, R. Morek, [w:] Regulamin Arbitrażowy Sądu Arbitrażowego..., s. 343-344; M.P. Wójcik, [w:] Kodeks postępowania cywilnego. Komentarz, t. 2. Art. 730-1217, red. A. Jakubecki, Warszawa 2017, s. 808.

30 Tak K. Weitz, Wyktad inauguracyjny na Konferencji... Podobnie A.J. Bělohlávek, R. Hótová, op. cit., s. 164, 198-201. Odmiennie B. Gessel-Kalinowska vel Kalisz, M. Dudzińska, op. cit., s. 461.

31 Por. T. Ereciński, K. Weitz, op. cit., s. 318; B. Krużewski, op. cit., s. 218-219; A.J. Bělohlávek, R. Hótová, op. cit., s. 188 oraz cyt. tam literatura; B. Gessel-Kalinowska vel Kalisz, M. Dudzińska, op. cit., s. 458; B. Krużewski, R. Kos, M. Modzelewska de Raad, op. cit., s. 12, 30.

32 A.J. Bělohlávek, R. Hótová, op. cit., s. 188 oraz cyt. tam literatura.

33 Ibidem, s. 166-167, 188 oraz cyt. tam literatura. 
modele ${ }^{34}$. Standardowo możliwe jest wyznaczenie biegłego przez sąd polubowny (tribunal appointed experts), przy czym przyjmuje się, że powinno to następować w porozumieniu ze stronami. W takiej sytuacji zwykle mają one również możliwość przedkładania dodatkowych opinii prywatnych celem weryfikacji stanowiska biegłego powołanego przez sąd arbitrażowy ${ }^{35}$. Przeważa jednak praktyka, zgodnie z którą biegły arbitrażowy wyznaczany jest przez strony — przyjmuje się wówczas, że odgrywa on rolę świadka dysponującego wiadomościami specjalnymi (expert witness) ${ }^{36}$.

W postępowaniu przed sądem polubownym — podobnie jak w postępowaniu przed sądem powszechnym — istnieje również możliwość powołania zespołów biegłych (w tym zespołów interdyscyplinarnych) ${ }^{37}$. Proponuje się także zastosowanie konstrukcji tak zwanego grupowania biegłych (odnoszącą się do biegłych

34 Wyraźne rozróżnienie w przedmiotowym zakresie wprowadza przykładowo Regulamin Dowodowy IBA. Odnośnie do dowodu z opinii biegłego powoływanego przez strony zob. art. 5 Regulaminu Dowodowego IBA (Party-Appointed Experts), a w zakresie biegłego powoływanego przez sąd arbitrażowy por. art. 6 Regulaminu Dowodowego IBA (Tribunal-Appointed Experts). W tym zakresie por. także przede wszystkim A.J. Bělohlávek, R. Hótová, op. cit., s. 163, 188; B. Gessel-Kalinowska vel Kalisz, M. Dudzińska, op. cit., s. 455; K. Czech, op. cit., s. 295-298. Zob. też Ł. Błaszczak, Dowodzenie w postępowaniu arbitrażowym, [w:] Dowody i postepowanie dowodowe w sprawach cywilnych, red. Ł. Błaszczak, K. Markiewicz, Warszawa 2015, s. 500-501. Por. także art. 20 ust. 3 i 4 Regulaminu ICC.

35 W tym zakresie por. też T. Ereciński, K. Weitz, op. cit., s. 318-319; B. Krużewski, op. cit., s. 218-220; A.J. Bělohlávek, R. Hótová, op. cit., s. 169, 172-173, 175, 188-190; T. Wiśniewski, M. Hauser-Morel, Postępowanie arbitrażowe, [w:] System Prawa Handlowego..., nb 197, s. 590; B. Gessel-Kalinowska vel Kalisz, M. Dudzińska, op. cit., s. 459-460. Zob. także art. 6 ust. 1 Regulaminu Dowodowego IBA, art. 29 ust. 1 Regulaminu UNCITRAL.

36 W tym zakresie por. też T. Ereciński, K. Weitz, op. cit., s. 318-319; B. Krużewski, op. cit., s. 220-221; A.J. Bělohlávek, R. Hótová, op. cit., s. 188-190; T. Wiśniewski, M. Hauser-Morel, op. cit., nb 197, s. 590; B. Krużewski, R. Kos, M. Modzelewska de Raad, op. cit., s. 27; K. Czech, op. cit., s. 280, 282, 292-294. Podobnie wypowiedział się również K. Weitz, Wykład inauguracyjny na Konferencji...

Uprawnienie stron do powoływania biegłych wynika przede wszystkim z autonomii stron w postępowaniu arbitrażowym, a także z przysługującego im ogólnego prawa do powoływania dowodów w postępowaniu arbitrażowym i zasady kontradyktoryjności. Kodeks postępowania cywilnego nie przewiduje wprost możliwości wyznaczania biegłych przez strony, ale wobec wyraźnie dyspozytywnego charakteru postanowienia art. $1191 \S 2$ k.p.c. („w braku odmiennego uzgodnienia stron”) nie ma wątpliwości, że strony mogą uzgodnić taki właśnie sposób wyznaczania biegłych. Możliwość wybierania biegłych przez strony przewidują wprost niektóre regulaminy arbitrażowe. Por. art. 5 Regulaminu Dowodowego IBA, art. 20 ust. 3 Regulaminu ICC, § 33 ust. 11 zd. 2 Regulaminu Sądu Arbitrażowego przy KIG. Odmiennie: § 32 Regulaminu Sądu Arbitrażowego przy Konfederacji Lewiatan, art. 29 ust. 1 Regulaminu UNCITRAL, § 12 ust. 1 Regulaminu Sądu Arbitrażowego przy DIG i art. 26 ust. 1 ustawy modelowej UNCITRAL. W tym zakresie por. też B. Krużewski, op. cit., s. 221; B. Gessel-Kalinowska vel Kalisz, M. Dudzińska, op. cit., s. 459-461; M. Łaszczuk, R. Morek, [w:] Regulamin Arbitrażowy Sądu Arbitrażowego..., s. 373.

37 Tak i więcej zob. B. Krużewski, R. Kos, M. Modzelewska de Raad, op. cit., s. 29. Por. też powołany tam art. 5 ust. 2 lit. (i) oraz art. 6 ust. 4 lit. (g) Regulaminu Dowodowego IBA. 
o tej samej specjalności), polegającej na tym, że sąd arbitrażowy wybiera dwóch biegłych — po jednym z listy przedstawionej przez każdą ze stron. Wskazani biegli mają wówczas wypracować wspólne stanowisko, co ma doprowadzić do złożenia przez nich wspólnej, spójnej i jednolitej opinii ${ }^{38}$. Dzięki temu rozwiązaniu sąd arbitrażowy nie odmawia stronom prawa do wskazania biegłych, którym ufają, stwarza jednak równocześnie mechanizm obiektywizujący ich pracę. Ideą wspomnianego rozwiązania jest zniwelowanie kontradyktoryjności biegłych stron przez wczesne połączenie ich w jeden zespół, którego praca może być koordynowana przez sąd arbitrażowy w porozumieniu ze stronami. Biegli zostają zmuszeni do współpracy, która powściąga pokusę stronniczości ${ }^{39}$.

Po trzecie, w analizowanym kontekście wypada zwrócić uwagę na fakt, że niezależnie od poczynionego zróżnicowania w postępowaniu arbitrażowym — inaczej niż w postępowaniu sądowym — dowód z opinii biegłego wyznaczonego przez stronę (a więc tak zwanego biegłego prywatnego) nie zostaje (w żadnym wypadku) „zdegradowany” do rangi dowodu z dokumentu prywatnego lub elementu stanowiska procesowego strony ${ }^{40}$. W arbitrażu opinia sporządzona przez eksperta na życzenie strony może być bowiem pełnowartościowym środkiem dowodowym ${ }^{41}$. W konsekwencji szczególnie relewantne problemy pojawiają się na gruncie opinii prywatnych. $Z$ istoty takiej opinii wynika bowiem, że strona każdorazowo będzie dążyć do tego, aby przedłożyć stanowisko dla niej korzystne ${ }^{42}$. Co więcej, koszty związane z wydaniem opinii przez biegłego opłaca strona, która go powołała ${ }^{43}$. Ostatecznie wynagrodzenie konkretnego biegłego może nawet zostać uzależnio-

38 Wspomniana metoda została zaproponowana na podstawie Protokołu K. Sachsa i N. Schmidta-Ahrendta. Tak i więcej na ten temat zob. B. Krużewski, op. cit., s. 223; B. Krużewski, R. Kos, M. Modzelewska de Raad, op. cit., s. 30-31; oraz K. Czech, op. cit., s. 348-349. W tym zakresie por. też B. Gessel-Kalinowska vel Kalisz, M. Dudzińska, op. cit., s. 458-459; M. Łaszczuk, R. Morek, [w:] Regulamin Arbitrażowy Sądu Arbitrażowego..., s. 377.

39 Tak K. Czech, op. cit., s. 348.

40 Tak M. Łaszczuk, R. Morek, Uwagi wprowadzające, [w:] Dowód z opinii biegłego..., s. 9; M. Łaszczuk, R. Morek, [w:] Regulamin Arbitrażowy Sądu Arbitrażowego..., s. 373. Odmiennie (w odniesieniu do dowodu z opinii biegłego powołanego przez stronę) B. Gessel-Kalinowska vel Kalisz, M. Dudzińska, op. cit., s. 460. Szczegółowo odnośnie do roli dowodu z opinii tak zwanego biegłego prywatnego w postępowaniu sądowym zob. P. Rylski, Prywatna opinia biegłego w postępowaniu cywilnym - analiza prawnoporównawcza, Warszawa 2009, passim, https://iws.gov.pl/ wp-content/uploads/2018/08/P-Rylski-Prywatna-opinia-bieg\%C5\%82ego-w-post\%C4\%99powaniu-cywilnym-2009.pdf (dostęp: 12.03.2019). W tym zakresie por. też J. Misztal-Konecka, Znaczenie tzw. opinii prywatnych dla postępowania cywilnego, MoP 2013, nr 2, s. $63 \mathrm{n}$.

41 T. Ereciński, K. Weitz, op. cit., s. 318.

42 Tak i więcej zob. B. Krużewski, R. Kos, M. Modzelewska de Raad, op. cit., s. 19-20. W tym zakresie por. też B. Krużewski, op. cit., s. 222; B. Krużewski, R. Kos, M. Modzelewska de Raad, op. cit., s. 13; M. Łaszczuk, R. Morek, Uwagi wprowadzajace, [w:] Dowód z opinii biegłego..., s. 11; K. Czech, op. cit., s. 286-287.

43 Por. B. Krużewski, R. Kos, M. Modzelewska de Raad, op. cit., s. 16 i 17; B. Gessel-Kalinowska vel Kalisz, M. Dudzińska, op. cit., s. 458, 460; K. Czech, op. cit., s. 307. 
ne od efektu — to znaczy wyniku danej sprawy (!) ${ }^{44}$. Wszystkie te okoliczności niewątpliwie rzutują na ocenę wiarygodności takiego eksperta ${ }^{45}$.

Jednak warto mieć na względzie, że biegły powinien pełnić funkcję pomocnika sądu — arbitrażowego - i to niezależnie od tego, w jaki sposób został powołany (przez stronę czy przez sąd polubowny) ${ }^{46}$. Nie ulega zatem kwestii, że każda opinia biegłego w arbitrażu powinna być niezależna i bezstronna ${ }^{47}$. W konsekwencji w postępowaniu arbitrażowym rodzi się konieczność złożenia przez biegłego oświadczenia co do jego niezależności i bezstronności (co — jak wynika z powyższego - ma szczególne znaczenie w odniesieniu do biegłego powołanego przez stronę). Wypada przy tym odnotować, że w postępowaniu sądowym biegły wpisany na listę biegłych sądowych nie składa zasadniczo za każdym razem przyrzeczenia, tylko powołuje się na przyrzeczenie złożone w momencie ustanowienia go w tym charakterze (por. art. $282 \S 1^{2}$ k.p.c.) ${ }^{48}$. W arbitrażu sytuacja kształtuje się zupełnie odmiennie. Zasadniczo nie ulega kwestii, że biegły arbitrażowy składa każdorazowo oświadczenie co do swojej niezależności i bezstronności (został bowiem powołany w konkretnej sprawie) ${ }^{49}$, a dodatkowo powinien również co do zasady złożyć przyrzeczenie (z tym że nieodebranie przyrzeczenia nie wpływa na

44 Tak P. Pietkiewicz, Wymogi dotyczące opinii biegłego, [w:] Dowód z opinii biegłego..., s. 40. Por. też B. Krużewski, R. Kos, M. Modzelewska de Raad, op. cit., s. 16 i 17. Odmiennie K. Czech, op. cit., s. 308 oraz cyt. tam literatura.

${ }^{45}$ W tym zakresie zob. też T. Wiśniewski, M. Hauser-Morel, op. cit., nb 197, s. 590; B. Krużewski, R. Kos, M. Modzelewska de Raad, op. cit., s. 13; M. Łaszczuk, R. Morek, Uwagi wprowadzające, [w:] Dowód z opinii biegłego..., s. 11; M. Łaszczuk, R. Morek, [w:] Regulamin Arbitrażowy Sądu Arbitrażowego..., s. 373; P. Pietkiewicz, op. cit., s. 40; K. Czech, op. cit., s. 286-287; T. Strumiłło, [w:] Kodeks postepowania cywilnego, t. 2. Komentarz. Art. 730-1217, red. J. Jankowski, Legalis 2019, komentarz do art. 1191 k.p.c., nb 13.

46 Tak B. Krużewski, R. Kos, M. Modzelewska de Raad, op. cit., s. 13, 17. Podobnie J. Szpara, op. cit., s. 33; M. Łaszczuk, R. Morek, [w:] Regulamin Arbitrażowy Sąu Arbitrażowego..., s. 373. Por. tez B. Krużewski, op. cit., s. 221-222; A.J. Bělohlávek, R. Hótová, op. cit., s. 193-195. Odmiennie (jak się wydaje) B. Gessel-Kalinowska vel Kalisz, M. Dudzińska, op. cit., s. 458; K. Czech, op. cit., s. 285-286.

47 Por. B. Krużewski, R. Kos, M. Modzelewska de Raad, op. cit., passim, w tym w szczególności s. 23; J. Szpara, op. cit., s. 33. Zob. też B. Krużewski, op. cit., s. 222; M. Asłanowicz, Sąd polubowny (arbitrażowy). Komentarz do części piatej Kodeksu postępowania cywilnego, Warszawa 2017, s. 112; K. Czech, op. cit., s. 358.

48 W tym zakresie por. też B. Krużewski, R. Kos, M. Modzelewska de Raad, op. cit., s. 18-19; P. Pietkiewicz, op. cit., s. 39-40. Zob. także A.J. Bělohlávek, R. Hótová, op. cit., s. 169, 175 i 190; B. Gessel-Kalinowska vel Kalisz, M. Dudzińska, op. cit., s. 458-459; oraz K. Czech, op. cit., s. $307-$ 309. Zob. też art. 5 ust. 2 lit. (c) oraz art. 6 ust. 2 Regulaminu Dowodowego IBA i art. 29 ust. 2 Regulaminu UNCITRAL.

49 Tak B. Krużewski, R. Kos, M. Modzelewska de Raad, op. cit., s. 15. Por. też P. Nowaczyk, op. cit., s. 385; M. Łaszczuk, R. Morek, Uwagi wprowadzajace, [w:] Dowód z opinii biegłego..., s. 10; M. Łaszczuk, R. Morek, [w:] Regulamin Arbitrażowy Sądu Arbitrażowego..., s. 373. W tym zakresie zob. także art. 29 ust. 2 Regulaminu UNCITRAL. Por. też propozycję wzoru oświadczenia biegłego w przedmiotowym zakresie: B. Krużewski, R. Kos, M. Modzelewska de Raad, op. cit., s. 20-21. 
wartość dowodu z opinii biegłego) ${ }^{50}$. Kwestia związana ze złożeniem przez takiego biegłego przyrzeczenia pozostaje jednak szczególnie problematyczna - dopuszczalność i zasadność odebrania przysięgi przez sąd polubowny rodzi bowiem istotne kontrowersje. W doktrynie zwraca się uwagę, że w analizowanej sytuacji widoczny jest podział między państwami common law, gdzie odebranie przyrzeczenia jest zazwyczaj możliwe, a państwami civil law, w których kompetencję do odbioru przysięgi rezerwuje się dla sądów państwowych ${ }^{51}$. Warto przy tym jednak podkreślić, że zgodnie z treścią art. $1184 \S 2$ zd. 2 k.p.c. sąd polubowny nie jest związany przepisami o postępowaniu przed sądem ${ }^{52}$. W konsekwencji w postępowaniu arbitrażowym nie ma podstaw do zastosowania (na zasadzie art. $13 \S 2$ k.p.c.) przepisu art. 282 k.p.c., regulującego zasady złożenia przyrzeczenia przez biegłego sądowego. W arbitrażu międzynarodowym obowiązek złożenia przyrzeczenia przez biegłego oraz jego treść często jest określana w regulaminach arbitrażowych lub przyjęta w praktyce ${ }^{53}$. Natomiast w krajowych postępowaniach arbitrażowych zespoły orzekające ograniczają się zazwyczaj jedynie do przypomnienia biegłemu o jego obowiązkach lub nawet rezygnują z takiego pouczenia ${ }^{54}$. W literaturze istotne kontrowersje budzi również kwestia, czy tego rodzaju pouczenie można traktować jako równoważne z uprzedzeniem o odpowiedzialności

50 Zob. M. Surdek, W. Sadowski, Dalsze czynności dotyczace opinii biegłego, [w:] Dowód z opinii biegłego..., s. 49.

51 Tak i więcej zob. K. Czech, op. cit., s. 328-329 oraz cyt. tam literatura zagraniczna.

52 W tym zakresie zob. też R. Morek, A. Budniak-Rogala, op. cit., komentarz do art. 1191 k.p.c., nb 5 ,

53 Tak M. Surdek, W. Sadowski, op. cit., s. 49. W tym zakresie por. też art. 8 ust. 4 Regulaminu Dowodowego IBA.

54 Tak M. Surdek, W. Sadowski, op. cit., s. 49. W tym zakresie por. też K. Czech, op. cit., s. 329-331. Zob. także art. 8 ust. 4 Regulaminu Dowodowego IBA.

De lege lata Kodeks nie rozstrzyga, czy sąd polubowny może odbierać od stron, świadków i biegłych przyrzeczenia. Dawniej zagadnienie to było uregulowane w art. $706 \S 1$ k.p.c. (pozytywnie), a jeszcze wcześniej w art. $502 \S 1$ k.p.c. z 1930 roku (negatywnie). W związku z tym przedmiotowa kwestia pozostaje szczególnie kontrowersyjna. Por. R. Morek, Mediacja i arbitraż (art. $183^{1}-183^{15}$, 1154-1217 k.p.c.). Komentarz, Warszawa 2006, s. 225; Ł. Błaszczak, M. Ludwik, op. cit., s. 168; T. Ereciński, K. Weitz, op. cit., s. 317; M. Łaszczuk, O dopuszczalności odbierania przyrzeczenia od świadków przez sąd polubowny, [w:] Międzynarodowy i krajowy arbitraż handlowy u progu XXI wieku. Księga pamiatkowa dedykowana doktorowi habilitowanemu Tadeuszowi Szurskiemu, red. P. Nowaczyk et al., Warszawa 2008, s. 69 n.; M. Łaszczuk, J. Szpara, op. cit., s. 28-30 i 34; K. Weitz, Przestanki i zakres pomocy sadu państwowego..., s. 110; A. Jakubecki, op. cit., s. 506-507; P. Pruś, [w:] Kodeks postępowania cywilnego. Komentarz, t. 2. Art. 506-1217, red. M. Manowska, Warszawa 2015, s. 1259-1260; T. Wiśniewski, M. Hauser-Morel, op. cit., nb 193, s. 589; B. Gessel-Kalinowska vel Kalisz, M. Dudzińska, op. cit., s. 462; K. Czech, op. cit., s. 329; M. Łaszczuk, R. Morek, [w:] Regulamin Arbitrażowy Sądu Arbitrażowego..., s. 366-367; A. Zieliński, [w:] Kodeks postępowania cywilnego. Komentarz, red. A. Zieliński, Warszawa 2017, s. 1813; A. Bieliński, [w:] Kodeks postepowania cywilnego, t. 4. Komentarz. Art. 1096-1217, red. A. Marciniak, Legalis 2019, komentarz do art. 1191 k.p.c., nb 5; R. Morek, A. Budniak-Rogala, op. cit., komentarz do art. 1191 k.p.c., nb 6; T. Strumiłło, op. cit., komentarz do art. 1191 k.p.c., nb 12. 
karnej za składanie fałszywych zeznań — w tym czy odpowiedzialność taka jest w ogóle dopuszczalna ${ }^{55}$. W konsekwencji przyjmuje się, że nieodebranie przyrzeczenia od biegłego nie wpływa w żaden sposób na wartość dowodu z jego opinii ${ }^{56}$.

Po czwarte, w efekcie szczególnie istotne pozostaje unormowanie standardów w zakresie niezależności i bezstronności biegłych w arbitrażu. W odniesieniu do biegłych w postępowaniu arbitrażowym nie znajdują bowiem zastosowania regulacje Kodeksu postępowania cywilnego (zwłaszcza art. 278-291) i inne przepisy dotyczące biegłych sądowych ${ }^{57}$. Nie istnieją również jakiekolwiek bezpośrednie regulacje w przedmiotowym zakresie statuowane na gruncie prawa arbitrażowego (omawiana kwestia nie jest bowiem poruszana ani w ustawie modelowej UNCITRAL ${ }^{58}$, ani w większości ustawodawstw arbitrażowych, ani też w wiodących regulaminach instytucji arbitrażowych) ${ }^{59}$. Standardy niezależności i bezstronności biegłych w postępowaniu arbitrażowym wywodzą się zatem z dokumentów o charakterze soft law (takich jak Regulamin Dowodowy IBA — por. w szczególności art. 5 ust. 2 lit. (a) i (c) oraz art. 6 ust. 2) ${ }^{60}$ oraz korporacyjnych zasad etycznych wiążących przedstawicieli poszczególnych zawodów ${ }^{61}$. Do pracy biegłych mają zastosowanie zasady (kodeksy etyki, best practices) wypracowane przez organizacje branżowe lub grupy zawodowe, do których biegli przynależą. Aktualnie rozważa się podjęcie próby skodyfikowania uniwersalnych zasad

55 Tak K. Czech, op. cit., s. 330 oraz cyt. tam literatura. Szczegółowo zob. M. Jamka, op. cit., s. 179-184. Por. też T. Ereciński, Zagadnienia prawa właściwego..., s. 57; R. Morek, op. cit., s. 225226; Ł. Błaszczak, M. Ludwik, op. cit., s. 168; T. Ereciński, K. Weitz, op. cit., s. 317; M. Łaszczuk, op. cit., s. 69 n., szczególnie s. 76-77; M. Łaszczuk, J. Szpara, op. cit., s. 29-30, 33 i 34; K. Weitz, Przesłanki i zakres pomocy sądu państwowego..., s. 110; P. Nowaczyk, op. cit., s. 379; A. Jakubecki, op. cit., s. 507; Ł. Błaszczak, op. cit., s. 497; P. Pruś, op. cit., s. 1259-1260; M. Asłanowicz, op. cit., s. 112; T. Ereciński, [w:] Kodeks postępowania cywilnego..., s. 957; M. Łaszczuk, R. Morek, [w:] Regulamin Arbitrażowy Sadu Arbitrażowego..., s. 366-367; A. Zieliński, op. cit., s. 1813; A. Bieliński, op. cit., komentarz do art. 1191 k.p.c., nb 5; R. Morek, A. Budniak-Rogala, op. cit., komentarz do art. 1191 k.p.c., nb 6.1; T. Strumiłło, op. cit., komentarz do art. 1191 k.p.c., nb 12.

56 M. Surdek, W. Sadowski, op. cit., s. 49.

57 Por. m.in. ustawa Prawo o ustroju sądów powszechnych z dnia 27 lipca 2001 roku (tekst jedn. z dn. 14.12.2018 r., Dz.U. z 2019 r., poz. 52) oraz rozporządzenie Ministra Sprawiedliwości w sprawie biegłych sądowych z dnia 24 stycznia 2005 roku (Dz.U. Nr 15, poz. 133). Tak M. Łaszczuk, R. Morek, Uwagi wprowadzające, [w:] Dowód z opinii biegłego..., s. 7; M. Łaszczuk, R. Morek, [w:] Regulamin Arbitrażowy Sądu Arbitrażowego..., s. 373.

58 Ustawa modelowa UNCITRAL (UNCITRAL Model Law on International Commercial Arbitration) — ustawa modelowa UNCITRAL o międzynarodowym arbitrażu handlowym uchwalona przez Zgromadzenie Ogólne ONZ i przyjęta przez Komisję Narodów Zjednoczonych ds. Międzynarodowego Prawa Handlowego (UNCITRAL/United Nations Commission on International Trade Law) w dniu 21 czerwca 1985 roku, a zmieniona dnia 7 lipca 2006 roku.

59 Por. B. Krużewski, R. Kos, M. Modzelewska de Raad, op. cit., s. 15 oraz cyt. tam literatura zagraniczna. Zob. też P. Nowaczyk, op. cit., s. 385.

60 Por. B. Krużewski, op. cit., s. 228. Szczegółowo w tym zakresie zob. B. Krużewski, R. Kos, M. Modzelewska de Raad, op. cit., s. 16-18. Por. też A.J. Bělohlávek, R. Hótová, op. cit., s. 190-193.

${ }^{61}$ B. Krużewski, op. cit., s. 228. 
działania ekspertów bez względu na dziedzinę wiedzy, w której się specjalizują. Wskazuje się, że ,ustalenie wspólnych zasad deontycznych obowiązujących biegłych jest tym bardziej potrzebne, że biegli prowadzą działalność w zróżnicowany sposób, a powoływanie tego środka dowodowego jest coraz częstsze"62. Stworzenie wspólnego kodeksu etycznego dla biegłych wszelkich specjalności pozostaje jednak szczególnie utrudnione właśnie ze względu na tę różnorodność przedmiotu ich działalności, a także z uwagi na problemy związane z ustaleniem jednolitych zasad odpowiedzialności ekspertów. Wydaje się zatem, że de lege ferenda warto byłoby rozważyć wyraźne uregulowanie odpowiedzialności biegłych w przepisach o charakterze bezwzględnie obowiązującym, a nie jedynie stricte w ramach zasad etycznych.

Po piąte, w praktyce i doktrynie arbitrażu przyjmuje się, że strony postępowania arbitrażowego mogą zgłaszać zastrzeżenia co do niezależności i bezstronności biegłych niezwłocznie po tym, jak dowiedziały się o ich podstawach ${ }^{63}$. W postępowaniu arbitrażowym brakuje jednak wyraźnej regulacji ustawowej stanowiącej odpowiednik art. 281 k.p.c. statuującego podstawy do wyłączenia biegłego. W związku z tym w praktyce arbitrażowej szczególnie relewantną rolę odgrywa kontradyktoryjny sposób weryfikacji opinii ekspertów ${ }^{64}$. W postępowaniu przed sądem polubownym nie ma bowiem bardziej bezpośrednich mechanizmów umożliwiających wyłączenie biegłego.

Wprawdzie z formalnego punktu widzenia brakuje podstaw, aby różnicować same standardy oceny niezależności i bezstronności ze względu na sposób powołania biegłych ${ }^{65}$. Jednak w praktyce (mając na względzie specyfikę danego środka dowodowego) stosuje się nieco odmienne sposoby weryfikacji opinii biegłego w zależności od tego, czy został on powołany przez zespół orzekający, czy też na zlecenie strony ${ }^{66}$. W przypadku powołania biegłego przez zespół orzekający weryfikacja opinii następuje zazwyczaj przez wezwanie biegłego na rozprawę i zadawanie mu pytań zarówno przez arbitrów, jak i strony (vide art. $1191 \S 3$ k.p.c.) ${ }^{67}$.

${ }^{62}$ Tak i więcej zob. B. Krużewski, R. Kos, M. Modzelewska de Raad, op. cit., s. 24-25. Por. też Analiza porównawcza przepisów dotyczących biegłych w państwach Austrii, Francji, Hiszpanii $i$ Wielkiej Brytanii oraz analiza polskich regulacji dotyczacych biegłych, https://www.bip.ms.gov. pl/Data/Files/_public/bip/ue_koop/Polen_Comprehensive_pl.pdf, s. 83 i 88 (dostęp: 20.03.2019).

63 Tak B. Krużewski, R. Kos, M. Modzelewska de Raad, op. cit., s. 21-22. Podobnie A.J. Bělohlávek, R. Hótová, op. cit., s. 173 i 175; P. Nowaczyk, op. cit., s. 385-386; Ł. Błaszczak, op. cit., s. 501. W tym zakresie por. też art. 6 ust. 2 Regulaminu Dowodowego IBA i art. 29 ust. 2 Regulaminu UNCITRAL.

64 Por. też B. Krużewski, op. cit., s. 222, 228.

65 Tak B. Krużewski, R. Kos, M. Modzelewska de Raad, op. cit., s. 15.

66 Ibidem, s. 13. Por. też B. Krużewski, op. cit., s. 224-226.

67 Por. B. Krużewski, R. Kos, M. Modzelewska de Raad, op. cit., s. 13. Zob. też T. Ereciński, K. Weitz, op. cit., s. 319; A. Jakubecki, op. cit., s. 507; P. Pruś, op. cit., s. 1260; B. Gessel-Kalinowska vel Kalisz, M. Dudzińska, op. cit., s. 462; T. Ereciński, [w:] Kodeks postępowania cywilnego..., s. 957; A. Bieliński, op. cit., komentarz do art. 1191 k.p.c., nb 5; T. Strumiłło, op. cit., komentarz 
Warto przy tym podkreślić, że szczegółowa procedura weryfikacji dowodu z opinii takiego biegłego została przykładowo przewidziana w Regulaminie Dowodowym IBA (por. art. 6 ust. 5 i 6$)^{68}$ oraz w Regulaminie UNCITRAL (art. 29 ust. 5$)^{69}$, a także w ustawie modelowej UNCITRAL (art. 26 ust. 2) ${ }^{70}$. Kompetencja stron w przedmiotowym zakresie została również określona w art. 20 ust. 4 Regulaminu ICC $^{71}$. W odniesieniu do biegłych powoływanych przez strony stosuje się natomiast metody polegające na przeprowadzeniu (1) przesłuchania biegłych ((re) direct-examination i (re)cross-examination), (2) konfrontacji biegłych lub (3) konferencji biegłych (expert witness conferencing lub hot-tubbing) ${ }^{72}$. Warto przy tym odnotować, że zgodnie z treścią art. 8 ust. 2 Regulaminu Dowodowego IBA sąd arbitrażowy zawsze sprawuje „pełną kontrolę” nad rozprawą główną. Przepis ten pozwala zadawać pytania, implikuje możliwość ich uchylania, a także umożliwia dokonanie przez sąd polubowny zmiany kolejności przesłuchań, wypracowanej przed rozprawą główną. W konsekwencji, chociaż w praktyce najczęściej to strony i ich zespoły prawnicze biorą na siebie ciężar prowadzenia przesłuchań, może również dochodzić do odwrócenia podziału ról w tym zakresie ${ }^{73}$.

Ostatecznie wypada podkreślić, że ocena dowodu z opinii biegłego pod kątem niezależności i bezstronności powinna następować na dwóch płaszczyznach — nie tylko (1) w odniesieniu do sporządzenia samej opinii, lecz także (2) w zakresie kontaktu ze stronami ${ }^{74}$. W konsekwencji, opierając się na przedmiotowej weryfikacji, (1) sąd polubowny może odmówić dopuszczenia dowodu z opinii biegłego z uwagi na sprzeczność z zasadami niezależności i bezstronności ${ }^{75}$. (2) W toku postępowania arbitrażowego może również dojść do wyłączenia wspomnianego dowodu ze względu na naruszenie standardów uczciwości postępowania i równości

do art. 1191 k.p.c., nb 13. Analogiczną regulację przewiduje $\S 33$ ust. 12 zd. 1 Regulaminu Sądu Arbitrażowego przy KIG.

68 B. Krużewski, op. cit., s. 225; B. Krużewski, R. Kos, M. Modzelewska de Raad, op. cit., s. 13-14; K. Czech, op. cit., s. 297.

69 Por. A.J. Bělohlávek, R. Hótová, op. cit., s. 174 i 176; oraz P. Nowaczyk, op. cit., s. 386-387.

70 B. Krużewski, op. cit., s. 224; A.J. Bělohlávek, R. Hótová, op. cit., s. 177-178.

71 A.J. Bělohlávek, R. Hótová, op. cit., s. 196-197.

72 Więcej zob. B. Krużewski, R. Kos, M. Modzelewska de Raad, op. cit., s. 14. W tym zakresie por. też B. Krużewski, op. cit., s. 225-226; A.J. Bělohlávek, R. Hótová, op. cit., s. 167, 210 214; P. Nowaczyk, op. cit., s. 387; B. Gessel-Kalinowska vel Kalisz, M. Dudzińska, op. cit., s. 463; M. Łaszczuk, R. Morek, Uwagi wprowadzające, [w:] Dowód z opinii biegłego..., s. 11-12; M. Surdek, W. Sadowski, op. cit., s. 49-54; K. Czech, op. cit., s. 284-290, 318-326, 331-342, 345-349 i 361-362. Por. też art. 8 ust. 3 Regulaminu Dowodowego IBA.

73 Tak i więcej zob. K. Czech, op. cit., s. 342-345 oraz cyt. tam literatura.

74 Tak B. Krużewski, op. cit., s. 226. Odnośnie do zasad kontaktu biegłego ze stronami w postępowaniu arbitrażowym zob. w szczególności P. Pietkiewicz, op. cit., s. 41-42; oraz J. Szpara, op. cit., s. 35-36.

75 Tak B. Krużewski, op. cit., s. 228. 
stron (fairness and equality of the parties) ${ }^{76}$. W przeciwnym wypadku podważenie dowodu z opinii biegłego arbitrażowego będzie możliwe ewentualnie dopiero w drodze skargi o uchylenie wyroku sądu polubownego lub w razie odmowy uznania albo stwierdzenia wykonalności wyroku sądu polubownego lub ugody zawartej przed tym sądem — z uwagi na (1) naruszenie klauzuli porządku publicznego (por. odpowiednio art. $1206 \S 2$ pkt 2 i art. $1214 \S 3$ pkt 2 k.p.c.) ${ }^{77}$ lub ewentualnie (2) naruszenie zasad postępowania przed sądem polubownym (vide odpowiednio art. $1206 \S 1$ pkt 4 i art. $1215 \S 2$ pkt 4 k.p.c.) czy też (3) pozbawienia strony możności obrony jej praw przed sądem arbitrażowym (zob. odpowiednio art. $1206 \S 1$ pkt 2 i art. $1215 \S 2$ pkt 2 k.p.c. $)^{78}$.

\section{PODSTAWY PRAWNE WYŁĄCZENIA BIEGŁEGO W POSTĘPOWANIU ARBITRAŻOWYM}

Ustawodawca nie wprowadził do kodeksu postępowania cywilnego wyraźnej regulacji statuującej podstawę prawną wyłączenia biegłego w postępowaniu arbitrażowym. Problematyczne pozostaje zatem, czy i na jakich zasadach miałoby to ewentualnie nastąpić. Specyfika wspomnianego dowodu w omawianym postępowaniu uzasadnia odmienne potraktowanie analizowanej kwestii, w zależności od tego, czy chodzi o biegłego powołanego przez stronę, czy też o biegłego powołanego przez sąd arbitrażowy. Wprawdzie w obu sytuacjach dopuszczalne jest uregulowanie przedmiotowego zagadnienia przez same strony, do kwestii wyłączenia biegłego może odnosić się również obowiązujący w danej sprawie regulamin arbitrażowy. W braku takowej regulacji rodzi się pytanie o istnienie jakichkolwiek podstaw do wyłączenia biegłego w postępowaniu przed sądem polubownym ${ }^{79}$.

Odnosząc się do przypadku biegłego powołanego przez sąd arbitrażowy, warto odnotować, że zgodnie z treścią przepisu art. 1184 § 2 zd. 2 k.p.c. sąd polubowny nie jest związany przepisami o postępowaniu przed sądem. W związku z tym

76 Tak B. Krużewski, op. cit., s. 228. Zob. też art. 9 ust. 3 lit. (e) Regulaminu Dowodowego IBA. W tym zakresie por. także § 33 ust. 6 Regulaminu Sądu Arbitrażowego przy KIG. Zgodnie z treścią powołanego przepisu zespół orzekający ocenia wiarygodność i moc dowodów według własnego przekonania, na podstawie wszechstronnego rozważenia zebranego materiału. Zespół orzekający ocenia na tej samej podstawie, jakie znaczenie nadać odmowie przedstawienia przez stronę dowodu lub przeszkodom stawianym przez nią w jego przeprowadzeniu.

77 W tym zakresie por. też A.J. Bělohlávek, R. Hótová, op. cit., s. 214-225; oraz M. Łaszczuk, R. Morek, [w:] Regulamin Arbitrażowy Sadu Arbitrażowego..., s. 354-355. Zob. także art. 34 ust. 2 lit. (b) pkt (ii) i art. 36 ust. 1 lit. (b) pkt (ii) ustawy modelowej UNCITRAL.

78 W tym kontekście por. też M. Łaszczuk, R. Morek, [w:] Regulamin Arbitrażowy Sąu Arbitrażowego..., nb 73-74, s. 354. Por. też art. 34 ust. 2 lit. (a) pkt (iv) i art. 36 ust. 1 lit. (a) pkt (iv) ustawy modelowej UNCITRAL i art. 34 ust. 2 lit. (a) pkt (ii) i art. 36 ust. 1 lit. (a) pkt (ii) ustawy modelowej UNCITRAL.

79 Tak K. Weitz, Wykład inauguracyjny na Konferencji... Por. też B. Krużewski, op. cit., s. 229. 
w postępowaniu arbitrażowym nie ma podstawy do zastosowania na mocy reguły z art. $13 \S 2$ k.p.c. przepisu art. 281 k.p.c dotyczącego wyłączenia biegłego sądowego. W doktrynie proponuje się zatem, aby w takiej sytuacji dopuścić analogiczne stosowanie regulacji kodeksu postępowania cywilnego (w tym w szczególności art. $1174 \S 2$ k.p.c.) statuujących zasady wyłączenia arbitra ${ }^{80}$. Wydaje się jednak, że sugerowane rozwiązanie pozostaje całkowicie bezzasadne. Można bowiem argumentować, że polski ustawodawca z rozmysłem pozostawił lukę w przedmiotowym zakresie, tym bardziej że przykładowo niemiecki Zivilprozessordnung zawiera wyraźną regulację, w myśl której do biegłego ustanawianego przez arbitrów stosuje się odpowiednio przepisy o wyłączeniu arbitra (vide $§ 1049$ ust. 3 z.p.o.) ${ }^{81}$. W konsekwencji w literaturze pojawia się postulat zastosowania wytycznych IBA dotyczących konfliktu interesów w międzynarodowym arbitrażu handlowym ${ }^{82}$. Wspomniane wytyczne odgrywają niewątpliwie znaczącą rolę w praktyce arbitrażu międzynarodowego; stosowane są również przez sądy powszechne ${ }^{83}$. Wytyczne IBA regulują zasady oceny niezależności i bezstronności arbitrów, są zatem idealnym fundamentem zastosowania mutatis mutandis $\mathrm{w}$ ramach weryfikacji podstawy ewentualnego wyłączenia biegłego w postępowaniu arbitrażowym ${ }^{84}$.

Dowód z opinii biegłego powołanego przez stronę nie stanowi natomiast dowodu z opinii biegłego sensu stricto — można bowiem przyjąć, że jest to (po prostu)

80 Tak (jak się wydaje) K. Weitz, Wykład inauguracyjny na Konferencji... Podobnie B. Gessel-Kalinowska vel Kalisz, M. Dudzińska, op. cit., s. 461; M. Łaszczuk, R. Morek, [w:] Regulamin Arbitrażowy Sadu Arbitrażowego..., s. 373.

81 Por. też B. Krużewski, op. cit., s. 229.

82 Por. B. Krużewski, R. Kos, M. Modzelewska de Raad, op. cit., s. 19. Zob. też P. Nowaczyk, op. cit., s. 385; K. Czech, op. cit., s. 358.

Dyrektywa IBA dotycząca konfliktu interesów w arbitrażu międzynarodowym (IBA Guidelines on Conflict of Interests in International Arbitration) została przyjęta 23 października 2014 roku przez Radę Międzynarodowego Stowarzyszenia Adwokatów (IBA/International Bar Association), zastępując ich poprzednią (pierwszą) wersję z 22 maja 2004 roku. Wspomniana dyrektywa nie jest wiążąca ani dla sądów powszechnych, ani dla trybunałów arbitrażowych, jeżeli uczestnicy wyraźnie się na nią nie powołają. W środowisku międzynarodowym i w niektórych regionach przyjmuje się jednak, że dyrektywy IBA dotyczące konfliktu interesów są odzwierciedleniem sprawdzonej praktyki. Powołują się na nie uczestnicy i biegli w przypadku podważenia postępowania arbitrażowego. Dyrektywa opiera się na katalogu możliwych sytuacji oznaczanych jako czerwone, pomarańczowe i zielone. Sytuacje opisane w tak zwanej czerwonej liście są przykładem konfliktu interesów uniemożliwiającego prawidłowe pełnienie funkcji. Lista pomarańczowa to przykładowe wyliczenie szczególnych sytuacji, które (w zależności od istoty sprawy) mogą wywołać uzasadnione wątpliwości dotyczące niezależności lub bezstronności arbitra. Konsekwentnie lista zielona prezentuje przykładowe sytuacje, w których z obiektywnego punktu widzenia nie występuje ani potencjalny, ani rzeczywisty konflikt interesów. Por. A.J. Bělohlávek, R. Hótová, op. cit., s. 190-193. Więcej zob. A. Szumański, Arbitrzy i zespół orzekający, [w:] System Prawa Handlowego..., nb 54 n, s. 435 n.

83 Zob. B. Krużewski, R. Kos, M. Modzelewska de Raad, op. cit., s. 19 i cyt. tam wyrok SA w Szczecinie z dnia 21 marca 2013 roku, I ACa 855/12, LEX nr 1344234; oraz post. SA w Gdańsku z dnia 11 lutego 2014 roku, I Acz 1475/13, LEX nr 1437925.

84 Więcej zob. B. Krużewski, R. Kos, M. Modzelewska de Raad, op. cit., s. 19. 
świadek mający wiedzę specjalistyczną (expert witness). W takim ujęciu opinia biegłego i jego wyjaśnienia są oceniane przez arbitrów tak jak każdy inny dowód. W efekcie jakiekolwiek wątpliwości co do niezależności i bezstronności biegłego należy uwzględniać przy dokonywaniu oceny wiarygodności danego biegłego. W konsekwencji nie ma jakiejkolwiek potrzeby posiłkowania się konstrukcją wyłączenia biegłego 85 .

\title{
DISQUALIFICATION OF AN EXPERT WITNESS IN AN ARBITRATION PROCEDURE
}

\author{
Summary
}

The legislator has not provided any specific regulations stipulating the legal basis of a disqualification of an expert witness in an arbitration procedure in the Polish Civil Procedure Code. As a result, it is clear whether it is possible and, if so, under what conditions it could take place.

The proceedings before the arbitration court are entirely distinct from litigation, and, therefore, there are different rules concerning the evidentiary procedure, especially obtaining an expert opinion. During the arbitration procedure, as opposed to litigation, there are two modes of obtaining said evidence. As a general rule, there is a possibility of appointing an expert witness by the arbitration court; however, it is more common for the parties to appoint an arbitration expert witness. This justifies the different approach to the matter of disqualification of an expert witness - on the basis of the source of their appointment.

Regarding the event of appointing an expert witness by the arbitration court, it is important to note that pursuant to the provision of Article $1184 \S 2$ sentence 2 of the Civil Procedure Code, the arbitration court is not bound by the provisions regulating the litigation. Therefore, in the arbitration procedure on the grounds of the rule stipulated by the provision of Article $13 \S 2$ of the Civil Procedure Code there is no legal basis to apply the provisions of Article 281 of the Civil Procedure Code regarding the disqualification of an expert witness. However, it appears that in the analyzed matter it is possible to resort to the IBA Guidelines on conflict of interests in international commercial arbitration. The expert witness appointed by the party shall be attributed the status of a witness with special knowledge (expert witness). With this approach there is no need to resort to disqualification of an expert witness - the evidence in question shall be evaluated based on rules on witness testimony.

Keywords: expert opinion, arbitration procedure, an expert witness in arbitration procedure, disqualification of an expert witness, disqualification of an expert witness in arbitration procedure

\section{BIBLIOGRAFIA}

Asłanowicz M., Sąd polubowny (arbitrażowy). Komentarz do części piątej Kodeksu postępowania cywilnego, Warszawa 2017.

Bělohlávek A.J., Hótová R., Biegli w środowisku międzynarodowym w postępowaniu: sądowym cywilnym i karnym oraz arbitrażowym, a także w sporach inwestycyjnych, Warszawa 2011.

85 K. Weitz, Wyktad inauguracyjny na Konferencji... 
Bieliński A., [w:] Kodeks postępowania cywilnego, t. 4. Komentarz. Art. 1096-1217, red. A. Marciniak, Legalis 2019, komentarz do art. 1191 k.p.c.

Błaszczak Ł., Dowodzenie w postępowaniu arbitrażowym, [w:] Dowody i postępowanie dowodowe w sprawach cywilnych, red. Ł. Błaszczak, K. Markiewicz, Warszawa 2015.

Błaszczak Ł., Ludwik M., Sądownictwo polubowne (arbitraż), Warszawa 2007.

Budniak-Rogala A., Charakter prawny zapisu na sad polubowny w postępowaniu cywilnym, Wroclaw 2015.

Budniak-Rogala A., Czy wszczęcie postępowania pojednawczego w sprawie objętej zapisem na sąd polubowny stanowi naduzycie prawa procesowego?, [w:] Ius est ars boni et aequi. Księga pamiatkowa dedykowana Profesorowi Józefowi Frąckowiakowi, red. A. Dańko-Roesler, M. Leśniak, M. Skory, B. Sołtys, Wrocław 2018.

Cieślak S., Stosunek postępowania arbitrażowego do innych rodzajów postępowania cywilnego, ADR 2011, nr 4, s. 15-34.

Czech K., Dowody i postępowanie dowodowe w międzynarodowym arbitrażu handlowym oraz inwestycyjnym, Warszawa 2017.

Ereciński T., [w:] Kodeks postępowania cywilnego. Komentarz, t. 6. Międzynarodowe postępowanie cywilne. Sad polubowny (arbitrażowy), red. T. Ereciński, Warszawa 2017.

Ereciński T., Zagadnienia prawa właściwego i postępowania dowodowego $w$ międzynarodowym arbitrażu handlowym, PiP 1987, z. 9, s. 49-63.

Ereciński T., Weitz K., Sąd arbitrażowy, Warszawa 2008.

Gessel Kalinowska vel Kalisz B., Przyczynek do rozważań na temat odrębności postępowania dowodowego w sprawach rozstrzyganych przez sady polubowne, ADR 2009, nr 1, s. 89-96.

Gessel-Kalinowska vel Kalisz B., Dudzińska M., [w:] Postępowanie przed sądem polubownym. Komentarz do Regulaminu Sąu Arbitrażowego przy Konfederacji Lewiatan, red. B. Gessel-Kalinowska vel Kalisz, Warszawa 2016.

Jakubecki A., [w:] Kodeks postępowania cywilnego. Komentarz, t. 5. Art. 1096-1217, red. H. Dolecki, T. Wiśniewski, Warszawa 2013.

Jamka M., Dowód z zeznań świadka w krajowej i międzynarodowej praktyce arbitrażowej, [w:] Księga pamiątkowa 60-lecia Sąu Arbitrażowego przy Krajowej Izbie Gospodarczej w Warszawie, red. J. Okolski, A. Całus, M. Pazdan, S. Sołtysiński, T. Wardyński, S. Włodyka, Warszawa 2010.

Krużewski B., Biegły w postępowaniu arbitrażowym, [w:] Księga pamiątkowa 60-lecia Sądu Arbitrażowego przy Krajowej Izbie Gospodarczej w Warszawie, red. J. Okolski, A. Całus, M. Pazdan, S. Sołtysiński, T. Wardyński, S. Włodyka, Warszawa 2010.

Krużewski B., Kos R., Modzelewska de Raad M., Wyznaczenie biegłego, [w:] Dowód z opinii biegłego w postępowaniu arbitrażowym. Raport Komisji ds. Arbitrażu Naczelnej Rady Adwokackiej, red. M. Łaszczuk, R. Morek, Warszawa 2016.

Kulski R., Postępowanie dowodowe przed sądami polubownymi w ujęciu prawa polskiego i prawa amerykańskiego, [w:] Mediacja i arbitraż jako instrumenty wspierania przedsiębiorczości, red. J. Olszewski, B. Sagan, R. Uliasz, Rzeszów 2006.

Łaszczuk M., O dopuszczalności odbierania przyrzeczenia od świadków przez sąd polubowny, [w:] Międzynarodowy i krajowy arbitraż handlowy u progu XXI wieku. Ksiega pamiatkowa dedykowana doktorowi habilitowanemu Tadeuszowi Szurskiemu, red. P. Nowaczyk, S. Pieckowski, J. Poczobut, A. Szumański, A. Tynel, Warszawa 2008.

Łaszczuk M., Morek R., [w:] Regulamin Arbitrażowy Sąu Arbitrażowego przy KIG. Komentarz, red. M. Łaszczuk, A. Szumański, Warszawa 2017.

Łaszczuk M., Morek R., Uwagi wprowadzające, [w:] Dowód z opinii biegłego w postępowaniu arbitrażowym. Raport Komisji ds. Arbitrażu Naczelnej Rady Adwokackiej, red. M. Łaszczuk, R. Morek, Warszawa 2016.

Łaszczuk M., Szpara J., Uwagi o zakresie pomocy udzielanej sądowi polubownemu przez sąd państwowy na podstawie art. 1192 k.p.c., „Palestra” 2008, z. 9-10, s. 27-35. 
Misztal-Konecka J., Znaczenie tzw. opinii prywatnych dla postepowania cywilnego, MoP 2013, nr 2, s. 63-69.

Morek R., Mediacja i arbitraż (art. $183^{1}-183^{15}$, 1154-1217 k.p.c.). Komentarz, Warszawa 2006.

Morek R., Budniak-Rogala A., [w:] Kodeks postępowania cywilnego. Komentarz, red. E. Marszałkowska-Krześ, Legalis 2019, komentarz do art. 1191 k.p.c.

Nowaczyk P., [w:] P. Nowaczyk, A. Szumański, M. Szymańska, Regulamin Arbitrażowy UNCITRAL. Komentarz, Warszawa 2011.

Pietkiewicz P., Wymogi dotyczace opinii biegłego, [w:] Dowód z opinii biegłego w postępowaniu arbitrażowym. Raport Komisji ds. Arbitrażu Naczelnej Rady Adwokackiej, red. M. Łaszczuk, R. Morek, Warszawa 2016.

Pruś P., [w:] Kodeks postępowania cywilnego. Komentarz, t. 2. Art. 506-1217, red. M. Manowska, Warszawa 2015.

Rylski P., Prywatna opinia biegłego w postępowaniu cywilnym - analiza prawnoporównawcza, Warszawa 2009, https://iws.gov.pl/wp-content/uploads/2018/08/P-Rylski-Prywatna-opinia-bieg\%C5\%82ego-w-post\%C4\%99powaniu-cywilnym-2009.pdf (dostęp: 12.03.2019).

Strumiłło T., [w:] Kodeks postępowania cywilnego, t. 2. Komentarz. Art. 730-1217, red. J. Jankowski, Legalis 2019, komentarz do art. 1191 k.p.c.

Surdek M., Sadowski W., Dalsze czynności dotyczace opinii biegłego, [w:] Dowód z opinii biegłego w postępowaniu arbitrażowym. Raport Komisji ds. Arbitrażu Naczelnej Rady Adwokackiej, red. M. Łaszczuk, R. Morek, Warszawa 2016.

Szpara J., Podstawowe zasady dotyczące pracy biegłego, [w:] Dowód z opinii biegłego w postępowaniu arbitrażowym. Raport Komisji ds. Arbitrażu Naczelnej Rady Adwokackiej, red. M. Łaszczuk, R. Morek, Warszawa 2016.

Szumański A., Arbitrzy i zespół orzekajacy, [w:] System Prawa Handlowego, red. S. Włodyka, A. Szumański, „Arbitraż handlowy” 8, red. A. Szumański, Warszawa 2015.

Szumański A., Pojęcie, rodzaje i charakter prawny arbitrażu handlowego, [w:] System Prawa Handlowego, red. S. Włodyka, A. Szumański, „Arbitraż Handlowy” 8, red. A. Szumański, Warszawa 2015.

Weitz K., Przestanki i zakres pomocy sadu państwowego dla sądu polubownego w postępowaniu dowodowym (art. 1192 k.p.c.), ADR 2009, nr 2, s. 107-118.

Weitz K., Wykład inauguracyjny na Konferencji pt. „Dowód z opinii biegłego w sądowym postępowaniu cywilnym i arbitrażu”, Warszawa 23.05.2017.

Wiśniewski T., Hauser-Morel M., Postepowanie arbitrażowe, [w:] System Prawa Handlowego, red. S. Włodyka, A. Szumański, „Arbitraż handlowy” 8, red. A. Szumański, Warszawa 2015.

Wójcik M.P., [w:] Kodeks postępowania cywilnego. Komentarz, t. 2. Art. 730-1217, red. A. Jakubecki, Warszawa 2017.

Zieliński A., [w:] Kodeks postępowania cywilnego. Komentarz, red. A. Zieliński, Warszawa 2017.

\section{ORZECZNICTWO}

Postanowienie SA w Gdańsku z dnia 11 lutego 2014 roku, I Acz 1475/13, LEX nr 1437925.

Wyrok SA w Szczecinie z dnia 21 marca 2013 roku, I ACa 855/12, LEX nr 1344234.

\section{INNE}

Analiza porównawcza przepisów dotyczacych biegtych w państwach Austrii, Francji, Hiszpanii $i$ Wielkiej Brytanii oraz analiza polskich regulacji dotyczacych biegtych, https://www.bip. ms.gov.pl/Data/Files/_public/bip/ue_koop/Polen_Comprehensive_pl.pdf, (dostęp: 20.03.2019).

Protokół CIArb (CIArb Protocol of Use of Party-Appointed Expert Witnesses in International Arbitration) - opracowany przez CIArb (Chartered Institute of Arbitrators) protokół doty- 
czący wykorzystania dowodu z opinii biegłych wyznaczonych przez strony w arbitrażu międzynarodowym.

Regulamin ICC (ICC Rules of Arbitration/International Chamber of Commerce Rules of Arbitration) - Regulamin (Postępowania Arbitrażowego) Międzynarodowego Trybunału Arbitrażowego przy Międzynarodowej Izbie Handlowej (ICC — International Chamber of Commerce).

Regulamin Dowodowy IBA (IBA Rules on the Taking of Evidence in International Arbitration) wydany przez Międzynarodowe Stowarzyszenie Adwokatów (IBA/International Bar Association) Regulamin IBA przeprowadzania dowodów w arbitrażu międzynarodowym, zatwierdzony 29 maja 2010 roku przez Radę Międzynarodowego Stowarzyszenia Prawników.

Regulamin Sądu Arbitrażowego przy Dolnośląskiej Izbie Gospodarczej we Wrocławiu, http://www. sa.dig.wroc.pl/files/regulamin_pl.pdf(dostęp: 8.05.2019).

Regulamin Sądu Arbitrażowego przy Konfederacji Lewiatan w brzmieniu obowiązującym od dnia 1 marca 2012 roku ze zmianami obowiązującymi od dnia 23 marca 2015 roku oraz od dnia 8 maja 2017 roku, http://www.sadarbitrazowy.org.pl/repository/Regulaminy/regulamin2017-PL-99x210-nowy.pdf (dostęp: 8.05.2019).

Regulamin Sądu Arbitrażowego przy Krajowej Izbie Gospodarczej w Warszawie w brzmieniu obowiązującym od dnia 1 stycznia 2015 roku, https://sakig.pl/wp-content/uploads/2018/12/ regulamin-arbitrazowy-tekst-jednolity-2015.pdf (dostęp: 8.05.2019).

Regulamin UNCITRAL (Regulamin Arbitrażowy UNCITRAL, UNCITRAL Arbitration Rules/Arbitration Rules of the United Commission on International Trade Law) - Regulamin Komisji Narodów Zjednoczonych ds. Międzynarodowego Prawa Handlowego (UNCITRAL/United Nations Commission on International Trade Law).

Ustawa modelowa UNCITRAL (UNCITRAL Model Law on International Commercial Arbitration) - ustawa modelowa UNCITRAL o międzynarodowym arbitrażu handlowym uchwalona przez Zgromadzenie Ogólne ONZ i przyjęta przez Komisję Narodów Zjednoczonych ds. Międzynarodowego Prawa Handlowego (UNCITRAL/United Nations Commission on International Trade Law) w dniu 21 czerwca 1985 roku, a zmieniona dnia 7 lipca 2006 roku.

Wytyczne CIArb (CIArb Guidelines on the use of Tribunal-Appointed Experts, Legal Advisers and Assesors) - opracowane przez CIArb (Chartered Institute of Arbitrators) wytyczne dotyczące wykorzystania dowodu z opinii biegłych wyznaczonych przez zespół orzekający oraz doradców prawnych i technicznych. 